\title{
PROCESS MAPPING IN A DENTAL CLINIC
}

\author{
Gabriel Nery da Silva ${ }^{1}$ \\ Luiz Teruo Kawamoto Jr. ${ }^{2}$ \\ Laiane Aparecida Soares Sena Nery ${ }^{3}$ \\ Waltraudi Orchulhak Kawamoto ${ }^{4}$ \\ Pietro Ayres Sanchini ${ }^{5}$ \\ Recebido em: 07 abr. 2018 \\ Aceito em: 23 abr. 2019
}

\begin{abstract}
This research aims to map the processes existing in a dental clinic. For such, field research procedures were adopted, which were performed at a union dental clinic located in São Paulo-SP city. The data collect was made through non-participant observation and focused (semi-structured) interview. The processes of the clinic were modeled with the aid of MS-Visio Professional 2013 software, in order to clarify the usefulness and participation of each component of the process. The flowcharts built in the research were validated with the technical coordinator of the clinic, who corrected their inconsistencies with the reality in the clinic. After that, the flowcharts were validated with an expert in management. The results make possible to understand the usefulness of each process and identify both the hierarchy of the processes and the key processes; and provide a basis for decision-making. Considering the business model of the clinic, the analysis of the results pointed out an opportunity of increasing the number of patients seen at the clinic. Process mapping provides a better understanding of the routines of the clinic as well as of their steps, and it may help managers to determine their processes and focus on them. So, it understands here that process management is applicable in dental clinics starting from process mapping.
\end{abstract}

Keywords: Process management. Health management. Productivity. Dentistry. Dental practice management.

\section{MAPEAMENTO DE PROCESSOS EM UMA CLÍNICA ODONTOLÓGICA}

RESUMO: Esta pesquisa busca mapear os processos em uma clínica odontológica. Para tanto, adotou-se os procedimentos de pesquisa de campo, os quais foram realizados em uma clínica odontológica de sindicato localizada na cidade de São Paulo-SP. A coleta de dados foi feita por observação não participante e entrevista semiestruturada focalizada. Os processos da clínica foram modelados com o auxílio do software MS-Visio Professional 2013, de modo a esclarecer a utilidade e a participação de cada componente do processo. Os fluxogramas construídos foram validados com o coordenador técnico da clínica, que corrigiu as incoerências destes com a realidade na clínica. Após isso, os fluxogramas foram validados com um especialista em gestão. Os resultados permitem entender a utilidade de cada processo e identificar a hierarquia dos processos e os processos-chave, e fornecem uma base para tomada de decisões. A análise dos resultados apontou uma oportunidade de aumentar o número de pacientes atendidos, considerando o modelo

\footnotetext{
1 Universidade de Mogi das Cruzes (UMC).

2 Instituto Federal de São Paulo (IFSP).

3 Universidade de Mogi das Cruzes (UMC).

${ }^{4}$ Universidade Brasil.

5 Universidade de Mogi das Cruzes (UMC).
} 
de negócios da clínica. O mapeamento de processos permite melhor entendimento da rotina da clínica e de suas etapas e pode auxiliar os gestores a determinar seus processos e focar neles. Assim, entende-se que há aplicabilidade de gestão por processo em clínicas odontológicas a partir do mapeamento de processos.

Palavras-chave: Gestão de processos. Gestão em saúde. Produtividade. Odontologia. Administração da prática odontológica.

\section{INTRODUÇÃO}

The concern to appropriate oral health is considered a prerequisite for the general health, social welfare, and quality of life of the population (BRASIL, 2004; MCCANN; LINK, 2007; PRASAD; VARATHARAJAN, 2011). Data from the Pesquisa Nacional de Amostra de Domicilios (PNAD) 2008 (BARROS; BERTOLDI, 2002; CHAVES et al., 2017; IBGE, 2010) show that although $88.3 \%$ of the population has passed through a dentist consultation, only $40.2 \%$ has done less than a year ago. When refining to those who have looked for dental service in the last two weeks, $76.6 \%$ have done in private clinics, whereas only $2.9 \%$ have done in ambulatories, or union dental office/clinic, or enterprise dental office/clinic, or first aid post, or emergency, or hospital.

Government projects and national policies aimed at oral health have as objective to provide dental services as a way to reduce the social inequalities with regards to oral health. However, the public services of such segment have not successfully reached this aim (MATOS et al., 2002). The supporting options are the private clinics, the university clinics, the unions' clinics, among others.

The dental clinic studied in this present study is an example of how many treatments a union dental clinic can offer, which may provide more health and well-being to the population. Also, if we consider the data of the PNAD 2008, the union dental clinics, as well as the others mentioned, may be seen as a stopped, idle resource with a low rate of utilization. Previous studies have already pointed out favorable prospects to the expansion of dental service offering associated with enterprises (JUNQUEIRA; RAMOS; RODE, 2005; SERRA; HENRIQUES, 2000; SILVEIRA; OLIVEIRA, 2002).

Moreover, besides the need for more considerable attention to this particular group to increase the pursuit of their services, it is also necessary to remember that any segment needs management. Although the health professional training is eminently academic and dedicated to patient well-being (LAGIOIA et al., 2008), when they begin to practice in clinics or offices they also need the ability of managing. According to a study performed in the State of Rio Grande do Sul, $52.77 \%$ of the dentistry students have chosen the course because of vocation, and $31.27 \%$ have some family member who practices the profession (CASSOL; DULLIUS; ANSUJ, 2016). The study also shows that practically all of them intend to attend a specialization course after they graduate, and $49.67 \%$ have already chosen which field. Even though such study is regional, it may be taken as an example that dentistry students intend to engage in the market and it corroborates the probability that they will be in clinics 
and will need to deal with managerial issues.

It notices in the literature a high amount of studies in the dentistry aimed at healthcare, infection controls, and improvement or building of new models of treatments, cures, or restorations (e.g. AL-DWAIRI, 2007; AL-OMARI; AL-DWAIRI, 2005; COULTHARD; HELEN, 2005; DOMÉJEAN; BANERJEE; FEATHERSTONE; 2017; KOHN et al., 2003), or studies analyzing new technologies (e.g. ALI et al., 2018; KAWAMOTO JR. et al., 2015). Yet, the amount of publications on management in dental clinics is inferior in comparison to the other themes (PRASAD; VARATHARAJAN, 2011). This issue stands out in hospital management (e.g. LAGIOIA et al., 2008; ROCHA et al., 2014; ROHNER, 2012).

Unlike the hospital management and even more the industry, where strategic management has come from, management in dentistry is scarce and incipient and needs attention to go on (BAHADORI et al., 2015; PRASAD; VARATHARAJAN, 2011; ROCHA et al., 2014). The literature emphasizes factors that affect the quality of dental services. The most is targeted at employees' competencies, skills, empathy, etc., i.e. behavioral aspects hoped from the professional (BAHADORI et al., 2015; CHOI et al., 2005; PRASAD; VARATHARAJAN, 2011); or interested in analyzing the patient perception in terms of service quality (BALDWIN; SOHAL, 2003); or in verifying the motives of patients complaints (PAULA et al., 2013). However, the most authors have taken into account neither the strategic management nor the organizing through management. Nevertheless, the specific literature shows that management is the way to achieve goals, no matter what goal is (DALL'ORSOLETTA; XAVIER, 2016; OLIVEIRA, S., 2014; OYADOMARI et al., 2014; SLACK; BRANDON-JONES; JOHNSTON, 2015; VAN DER AALST, 2013).

A dental clinic has the same characteristics that any organization does (SAM; BONNICK, 2011) and as such it performs the same activities typically presents in organizations, such as accounting/bookkeeping (e.g. NELSON, 2008), human resources (e.g. HOLMES et al., 2010), purchase and storage of materials and goods, customer support (e.g. AHMED; AMAGOH, 2014), execution of accounts payable and receivable, etc. which necessarily need strategic management to ensure the business continuity and growth in the market. Managers who strive to in-depth management in dental clinics such as the unions' clinics or the others less popular may increase their potentials, which, in turn, may result in more patients to be seen. Nevertheless, such group will face competition against the other modalities of dental clinics, which likewise seek to gain new customers and increase the profitability. In the field of health, the role of the customer is assumed by patients (ROHNER, 2012; SILVA et al., 2015).

The literature also points out the quality service perception (BALDWIN; SOHAL, 2003). On the one hand, Rohner (2012) affirms that in the area of health the focus is on obtaining an outcome, being such outcome a cure or an improvement. On the other hand, some authors affirm that the customer satisfaction is seen as the most important objective in the medical sector, especially in dentistry (AHMED; AMAGOH, 2014; CAMGÖZ-AKDAĞ; ZINELDIN, 2010). In both cases, the adequate performance is a critical component. In any segment, either industrial or service provision, customers want a high-quality service and 
with the least waiting time (AHMED; AMAGOH, 2014; BAHADORI et al., 2015; CHOI et al., 2005; PRASAD; VARATHARAJAN, 2011).

The customers of the dental segment have more sensibility to the price due to the particular dentistry characteristics, such as the broader range of procedural options and materials to perform a specific treatment (COVRE; ALVES, 2002), which inevitably influence on the final price of service (PRASAD; VARATHARAJAN, 2011). This customer sensibility leads him/her to analyze factors in order to choose which clinic among many options s/he will look for treatment. It notices in such situation an example of competitiveness in the segment.

This research is justified by the need of strategic management existing in all segments in order to stay in the competitive and dynamic market, where everything changes fast, and we are passing through the fourth industrial revolution (LI; HOU; WU, 2017; MAYNARD, 2015), which requires new models of processes that bring competitive edges to the organizations (SANCHEZ; FREITAS, 2015), and it is necessary to measure all this. Besides, the customers/patients have been becoming more demanding every day (AHMED; AMAGOH, 2014; BALDWIN; SOHAL, 2003; CAMGÖZ-AKDAĞ; ZINELDIN, 2010; CARVALHO; PALADINI, 2012; OLIVEIRA, S., 2014; PAULA et al., 2013). This research is also justified by the fact that certain groups of dental service providers have been neglected in the academic field, which indicates a lack of studies in the area. Also, as far as management is concerned, dentists may not know in a technical way how processes, operations, and/or management work, such as the lack of knowledge of a large number of dentists about the Organização Nacional de Acreditação (ONA) (PINTO, 2015). This condition can lead to loss of competitiveness and quality of service.

With this in mind, process management may be useful, since through management it is possible to find negative points and propose improvements to mitigate or eliminate mishaps, all based on information collected through process mapping. Keeping that in mind, and as a first step to, this research intended to study the processes existing in a dental clinic and map them to provide information regarding the clinic's routine and the sequences, interrelations, and interconnections of its processes in order to propose improvements where were necessary, aiming for meeting the clinic's business model. When utilizing techniques as process mapping, dentistry practitioners will be able to adjust and design their clinics to reach potential gains through processes better developed and appropriate, patientoriented.

So that this present research hypothesized that the process mapping in a dental clinic would provide an understanding of its activities and so the opportunities for improvement would have become clearer (SLACK; BRANDON-JONES; JOHNSTON, 2015), paving the way for investments in productivity, increase in profitability, and improvement in the quality of the services.

The general objective of this research is to map the processes existing in a dental clinic. The specific objectives are to (1) interview a manager or head of a dental clinic to obtain data on the operation of the clinic; (2) provide that the head of the clinic determine 
the clinics' processes; (3) propose suggestions to fit the clinic's business model.

\section{LITERATURE REVIEW}

\section{PROCESS MANAGEMENT}

Process may be understood as: a sequence of organized activities that transform the inputs from suppliers into outputs for customers, with a value-added generated by the unity (ROTONDARO, 2012); or as a collection of activities with one or more entrances that generate one or more results that represent value for the internal or external customer (HAMMER; CHAMPY, 1994); or as a set of ordered and integrated actions for a specific productive purpose, from where products and/or services and/or information will be generated at the end (OLIVEIRA S., 2014). Gonçalves (2000) wrote: it is remarkable the variety of processes that we can find in companies.

Process management is a method for continuous assessment, analysis, and improvement of the performance of the processes that most impact on the customer satisfaction and the company's shareholders (ROTONDARO, 2012). It is also seen as an administrative approach performed by an organization that seeks the optimization and the improvement in the chain of their processes (UNICAMP, 2003). Oliveira S. (2014) supports another more operational definition, and so he defines process management as an Organizing Management Model oriented to manage the organization by focusing on processes. Llanes-Font et al. (2014) say that the purpose of process management is to improve the efficiency and effectiveness of the organization in order to achieve defined objectives.

Process management is a managerial vision with characteristics of a series of other visions, such as Scientific Administration (TAYLOR, 1990), Just-in-Time system (OHNO, 1997), Business Process Reengineering (HAMMER; CHAMPY, 1994), Theory of Constraints (GOLDRATT; COX, 2014), and Quality Management System (CARVALHO; PALADINI, 2012; GARZA-REYES, 2018; OLIVEIRA, S., 2014; TOBÓN; BOLÍVAR, 2004). It divides the process into three major hierarchical categories: macro-process, processes, and sub-processes (OLIVEIRA, S., 2014; SLACK; BRANDON-JONES; JOHNSTON, 2015; ROHNER, 2012; UNICAMP, 2003).

Macro-process is the reason for the existence of an organization. It is directly related to the mission of the organization, i.e. its objective (ROCHA et al., 2014; SLACK; BRANDON-JONES; JOHNSTON, 2015; ROHNER, 2012). Processes are the set of interconnected activities needed to achieve the macro-process objectives. They are equivalent to company departments and have the characteristic of input and output. In other words, processes start and finish with the external customer (SLACK; BRANDON-JONES; JOHNSTON, 2015; ROHNER, 2012; UNICAMP, 2003), being the supplier also 
characterized as a customer, in this case. Sub-processes are the group of activities that comprise a process but may also involve more departments (OLIVEIRA, S., 2014; ROCHA et al., 2014; SLACK; BRANDON-JONES; JOHNSTON, 2015; ROHNER, 2012; UNICAMP, 2003). The activities and tasks are below the sub-processes and are sequenced and isolated works that are typically performed by a single department or even by only a single person (OLIVEIRA, S., 2014; UNICAMP, 2003).

Process management allows for business processes identification, which are managed through Business Process Management (BPM) techniques. BPM is a method of organizing the company in order to align it with its strategic objectives and/or improve its organizational performance (KIRCHMER; LAENGLE; MASIAS, 2013; OLIVEIRA, S., 2014; OLIVEIRA, S.; MOTTA; OLIVEIRA, A., 2012; VAN DER AALST, 2013).

The literature points out some benefits of process management, such as (LIN; YANG; PAI, 2002; OLIVEIRA, S., 2014; OLIVEIRA, S.; MOTTA; OLIVEIRA, A., 2012; ROTONDARO, 2012; TOUSSAINT, 2013; UNICAMP, 2003):

- Process improvement;

- Reduction of process costs;

- Reduction of process times;

- Increase in process quality;

- Improvements in the results; and

- Increased customer satisfaction.

In the literature, there are some examples of practical studies of process management, such as Sánchez and Rodríguez (2007), who show how a hospital group monitories the performance and quality of its processes stemming from the identification of both the key processes and the other business processes. According to the hierarchy of the processes, the hospital group dedicates different kinds of attention.

Lagioia et al. (2008), through process management, standardized the processes of a hospital unity and measured the effectiveness through a before and after comparison that was registered in the performance indicators. The results show a reduction in the mean waiting period of admission to surgery, in the average time of surgery duration, in the number of days for length of patient's stay, and in the direct costs of inpatient period. However, there was no cost reduction in the materials consumed during the surgery.

Longaray et al. (2015) used BPM to propose the redesign of the processes of container handling in a retroportuary terminal in the State of Rio Grande do Sul, where the authors optimized the process and measured the effectiveness. After the identification of the process bottleneck, the authors redesigned the process and assessed it, reaching a reduction of $44 \%$ in the container handling. 
Rocha et al. (2014) implanted process mapping in the human resources management sector of a hospital aiming for process standardization, where they then could monitor the processes in order to bring on improvement in the hospital services which are directly and indirectly dependents on this sector. The authors followed four steps described in the study: (1) a survey of data and critical processes; (2) validation with the manager of the sector to certify the coherence; (3) process redesign; and (4) process modeling. Through these methods, the authors identified the hierarchy of processes, which were the key processes and the critical points. With the process mapping, the processes of the sector were standardized and sequenced.

However, over our researches, we did not find the practice of process management specifically in dental clinics.

\section{GRAPHICAL REPRESENTATION OF PROCESSES}

In order to facilitate the understanding of the accurate processing of a particular workflow, graphical representation with figures and symbols is used, in an outlined way. With regards to the graphical representation of processes, the flowchart is the commonest, which represents the natural workflow of any work, product, or document (CURY, 2000). For Oliveira D. (2007), a flowchart is a graphical representation that represents the sequence of a work in an analytical way, characterizing the operations, responsible, and/or organizational unities involved in the process.

The act of representing organizational systems through flowcharts to help the strategic management and the company organizing is also called process modeling or mapping, which is the vision of a company through the building of functional diagrams about the process behaviors (OLIVEIRA, S., 2014). Process modeling allows to have a panoramic vision of the business process of a company and then identify critical factors, highlight strong and weak points, and understand the usefulness of each process, among others (ARAUJO, 2001; CURY, 2000; OLIVEIRA, D., 2007; OLIVEIRA, S., 2014).

There are several techniques of graphical representation through flowcharts, and each provides a different panoramic vision, from the simplest to the most complex and detailed (ARAUJO, 2001; OLIVEIRA, D., 2007). The horizontal flowchart (Swim lane) is considered the most overarching. It serves to represent the roles (functions) that are carried out by different actors that interact in the processes, i.e. it allows to visualize the dynamic that occurs amongst the processes and identify the actors and their responsibilities (OLIVEIRA, S., 2014).

\section{DENTAL CLINIC}

On the Health Science Descriptors (DeCS, 2018) website, dental clinic is defined as facilities where dental care is provided to patients. The Conselho Federal de Odontologia 
(CFO) and Conselho Regional de Odontologia de São Paulo (CROSP) consider dental clinics and dental offices as the place or companies that have the provision of dental care as the primary activity (CFO, 2005; CROSP, 2017a, 2017b). Dental office and dental clinic are distinguished from one another mainly by their sizes. The first one is characterized by having only a set of dental equipment, keeping attached or not a laboratory of dental prosthesis; and the second one is characterized by having a set of three dental offices at most, independent of each other, with a common waiting area, and keeping a laboratory of dental prosthesis attached (CFO, 2005; CROSP, 2017a, 2017b; SÃO PAULO, 1999). This present study considers both dental clinic and dental office as being facilities where dental care is provided to patients, and, independent of the size, are referred to as dental clinic.

\section{BUSINESS MODELS IN DENTAL CLINICS}

The concepts of business model have emerged and grown over the last two decades (PELS; KIDD, 2015). Business model is understood as the way how the organizations make business, different from what they do (ZOTT; AMIT; MASSA, 2011). That is, which strategic or way an organization uses to achieve their aims.

According to Morris, Schindehutte and Allen (2005), and Pels and Kidd (2015), there are three different operational levels in business model: the economic level, which corresponds to the way the business model generates profits; the operational level, which corresponds to the organization's infrastructure that enables it to create value; and the strategic level, which refers to the market positioning of the business and the overall direction of the organization.

In dental clinics, those of the public sector aim to meet the basic oral health needs of the population. In this context, the focus is on providing services to the largest possible parcel of the population. The mechanism utilized to is the Sistema Único de Saúde (SUS) (BRASIL, 2004; MATOS et al., 2002). The business model is then to meet the worst cases, in the first place, followed by the meeting of the highest possible number of patients.

The clinics of the private sector are legal entities with profit motives (BRASIL, 1998). Thus, they have the profitability as a business model (PRASAD; VARATHARAJAN, 2011). In this situation, the focus is on obtaining the highest profits from the provided treatments. It is common in legal entities with profit motives the $80 / 20$ Pareto principle, where $20 \%$ of the provided products (or services) are responsible for $80 \%$ of the organizations' profits (CARVALHO; PALADINI, 2012; SLACK; BRANDON-JONES; JOHNSTON, 2015).

The union dental clinics are classified in the self-management modality. The clinics of such modality operate services associated with enterprises and have the aim of providing assistance and treatments to the employees (union members) and their families (AGÊNCIA NACIONAL DE SAÚDE SUPLEMENTAR, 2000) in order to provide more quality of life to the workers (PIETROBON et al., 2008). As the health plan is provided through a fixed monthly fee that is paid by the union member to the union, all the services provided by the 
dental clinic have the same price. So, this is similar to what Kotler and Keller (2012) call products mix, with the price defined in the modality of product bundle pricing. Thus, the treatments that most generate profits are not necessarily the priorities of a union dental clinic. The business model is the productivity, and this is measured by the number of patients seen.

The university dental clinics are based on the principle that teaching extension practices are indispensable for student learning. Thereby the primary objective of these clinics is educational, i.e. they intend to offer an opportunity for practicing execution of what the students have been studying. So that they expose the students to the demands which they will meet in the society (MARTINS et al. 2016; SÃO PAULO, 1999; ZILLI et al., 2017). The existing of university clinics supports the SUS since this one is unable to meet all the demand (ZIROLDO; GIMENES; CASTELO JR., 2013). In this context, the business model of university dental clinics focuses on meeting a variety of kinds of treatments.

Although there is diversity in the business models of the health service providers, the standardization of procedures and processes is seen as necessary to assign continuity to the business (PINOCHET; LOPES; SILVA, 2014).

\section{QUALITY}

Quality is a theme on which much has been said, written and developed over the past two decades (PIRES, 2014). It depends on the customer, i.e. the final consumer of a specific product or service. It is also a competitiveness factor for the organizations. In short, Quality may be defined as customer satisfaction. Thus, organizations seek to offer their products or services in a way that meets what the customer expects, which may increase the chances of repetition and recommendation (SILVA et al., 2015). So the quality parameter is the customer perception. Marketing is its powerful ally since it is the Science that identifies both the consumer and its needs (KOTLER; KELLER, 2006).

Historically, quality has been through several changes of conceptions and addressing because of the increasing competitiveness between companies, which have been increased as an exponential function over the years, always seeking the customer satisfaction through different ways to control it (TOBÓN; BOLIVAR, 2004). Recently, the concern on customer experience, i.e. the concern to provide to customers/patients a unique service experience, has also been emerged. The idea of customer experience, which is dedicated of representing the interaction between customer and service provider (MEYER; SCHWAGER, 2007; SILVA et al., 2015), considers the customer's subjective perception to assess the possibility of recommendation. Besides to provide a parameter to improve the service quality, it is also seen as a competitive advantage (SILVA et al., 2015).

It is important to observe that the functional addressing of Quality is recent, i.e. Quality has become a managerial function recently, but in effect, it is conceptually known for centuries (GOZZI, 2015). For this research, it is considered the aspect of quality as 
valued-added to product or service to meet the customers/patients needs and expectations.

\section{MATERIALS AND METHODS}

\section{RESEARCH CLASSIFICATION}

This study is an applied research (GIL, 2010; THIOLLENT, 2013), descriptive, qualitative (MARCONI; LAKATOS, 2008; MINAYO, 2016), transversal and interdisciplinary. The study design is the field research (FERRARI, 1982; MARCONI; LAKATOS, 2009). The methodological procedures followed the monographic and structured methods (MARCONI; LAKATOS, 2009; GIL, 2010). The techniques utilized to collect the data were (ANDER-EGG, 1978): (a) systematic non-participant observation; (b) focused (semi-structured) interview, which was conducted with a head of a dental clinic.

\section{RESEARCH ENVIRONMENT}

This research was conducted at a dental clinic that has been acting in the market for more than thirty years and has emerged to meet the demands of a class union in São Paulo city. It has three units, two of them are located in the center of São Paulo, and the third one is located in Santo Amaro. Its identity will be preserved. As it is a union dental clinic, the strategic pillar of its business model is the highest number of patients seen, i.e. productivity, and as such it differs from other dental clinics for not having as focus the highest possible profit. Therefore, the treatment with a high-profit margin is not necessarily seen as the most important for this kind of clinic. The clinic has thirty-two dentists and a technical coordinator. One of the dentists works four days a week, and everyone else works two days a week. The clinic also has four assistants, sixteen attendants, three technicians in oral health, who attend one day a week each; and an administrative coordinator. The services provided at the clinic are: a) Surgery; b) Clinic; c) Periodontics; d) Endodontics; e) Orthodontics (charged separately); f) Dental Prosthesis (charged separately); g) Pediatric Dentistry; h) Prophylaxis. These are the Specific Dental Services (SOE) of the clinic, which ramify and expand according to each necessity and specialty. The dentists are the professionals capable of performing the most of such dental treatments (CFO, 2005). Both the assistants and the attendants perform services that support the dentists, such as X-ray and sterilization of equipment. The oral health technicians perform the tooth prophylaxis (cleaning) of the union members.

The answers to the interviews were provided by the technical coordinator (who will have his identity preserved). He is a dentist with ten years of experience, specialization, master and doctoral degrees. He is also a college Professor. 
For this study, there are no risks of physical, psychological, moral, or religious nature for those who are a participant or involved.

\section{RESEARCH DELIMITATION}

This research is limited to investigate and map the processes existing in a dental clinic which are related to health, i.e. the processes that involve medical procedures/treatments or are directly related to them; since the research intends to contribute with the field of quality in health services. It was not considered data as (a) how much time each activity, task, or process require to be carried out; (b) quantity of employees to perform any activity; costs and prices of the products and services.

\section{DESCRIPTION OF THE METHODOLOGICAL PROCEDURES}

First of all, a literature review was conducted in order to base the concepts which would be utilized in this research, know about the study environment, and reflect the state of the art. Next, visits to the dental clinic previously described were done to collect the data. The visits had as a premise to know and register how the clinic is, regarding the physical installation of resources, equipment, and machines; departmental or sectional division, and mainly which kind of process happens there. Over five weeks the day to day of the clinic was observed to know its natural workflow, and annotations were done about it, all of this was supported by explanations from the technical coordinator (the interviewee) whenever necessary. In these visits, the following steps were followed:

- Set the strategic objective of the clinic;

- Written and sequential registers of all the processes existing in the clinic;

- Macro-process identification;

- Processes identification;

- Sub-processes identification;

- Flowcharts building (process mapping) of all the main processes;

- Data analysis and suggestions for improvements.

In the step of processes registering, flowcharts of all the processes of the clinic were elaborated, without applying any modification or suggestion of change. Initially, the objective was to understand how precisely the routine of the clinic was.

For flowcharts building, MS-Visio Professional 2013 software was chosen. It is a flexible tool and has broad popularity and recognition in the market (ALMEIDA NETO, 2014). Also, the authors of this research have familiarity with the software. 
In this first step, the information collected in the non-participant observation and the interview was the basis for flowcharts elaboration. Next, the flowcharts were checked by the interviewee to validate their coherence with the reality (ROCHA et al., 2014). According to him, they were not correct, because it was missing to discriminate the process of checking monthly fee, which is performed at the reception. Therefore, the flowcharts were corrected and the interviewee rechecked them. In this verification, he corrected errors at the ending of some processes, especially those which do not end in themselves, but rather refer the patient to another treatment, such as paraendodontic and retreatment, which, depending on the result, may refer the patient to extraction or restoration treatments. In the third verification, further clarifications about the warranty process were necessary, as well as its requisites and prerequisites, decision criteria, and procedures to be adopted. Corrections in the macro-process were also necessary. Then, new corrections were done and both the warranty process and the macro process were redesigned and the interviewee rechecked them.

Some of the processes modeled in the research are presented in the next section. However, to understand them, as well as their dynamics and identification numbers, a reference guide (Supplementary Table S1) was necessary.

A five-point Likert scale was used to validate the flowcharts with the technical coordinator of the clinic (where 1 = strongly disagree and $5=$ strongly agree). It was asked him whether the language is intelligible, accessible, and objective; and whether they represent the reality of the clinic's processes.

The last stage was suggesting improvements. Such suggestions were carried out based on the literature and had focused on:

- Ascertaining processes which have presented failures, complexities, or could compromise the productive flow of the clinic. For such processes, comments were carried out concerning their relevancies, and then proposals were made to increase perhaps either the number of patients seen or the patients' satisfaction; and

- Considering the dentist opinion regarding possible suggestions for changing any process.

Finally, the flowcharts were validated with an expert in management. He is Master of Technology degree in Service Management, Ph.D. in Biomedical Engineering, Specialist in Business Administration, MBA International Executive, and Bachelors of Business Administration degree. He is also a business consultant, college Professor, and author of books.

Considering a five-point Likert scale (where 1 = strongly disagree and $5=$ strongly agree), it was asked him whether the flowcharts correctly utilize the concepts of process mapping and process management. 


\section{RESULTS}

According to the interviewee, the strategic objective of the clinic is to meet, with quality, as many patients as possible. Therefore, the treatments that most generate profits are not a priority, but rather the attendance of the highest number of patients is.

The flowcharts presented here are the products from the process mapping. It is possible to notice clarity in the sequences and the interconnections between the processes, as well as understand their relationships and study opportunities of acting to improve any of them, as the literature predicts (CAMGÖZ-AKDAĞ; ÇALIŞKAN; TOMA, 2017; GONÇALVES, 2000; LAGIOIA et al., 2008; LIN; YANG; PAI, 2002; LLANES-FONT et al., 2014; OLIVEIRA, S., 2014; ROCHA et al., 2014; SLACK; BRANDON-JONES; JOHNSTON, 2015).

Altogether, the processes registered and modeled have reached twenty-three processes, including the macro-process. This one addresses from the first patient contact with the clinic, either through urgency or appointment, until the last appointment, when the patient is discharged. The macro-process also addresses the post-sales services, and only after that it finally ends. Figure 1 represents the macro-process of the clinic studied in this research. It notices some initial stages where the patient has to pass through, such as Xray and triage, when then $\mathrm{s} / \mathrm{he}$ is finally referred to the destined treatment, one of the SOE of the clinic. There is no automatizing arrival control, such as service ticket. When the patient arrives at the clinic s/he waits for calling.

The processes that most drew our attention are presented in this present paper. For more details on the other processes, see Supplementary Materials: Fig. S1-S20.

Figure 1. Flowchart of the macro-process of the clinic

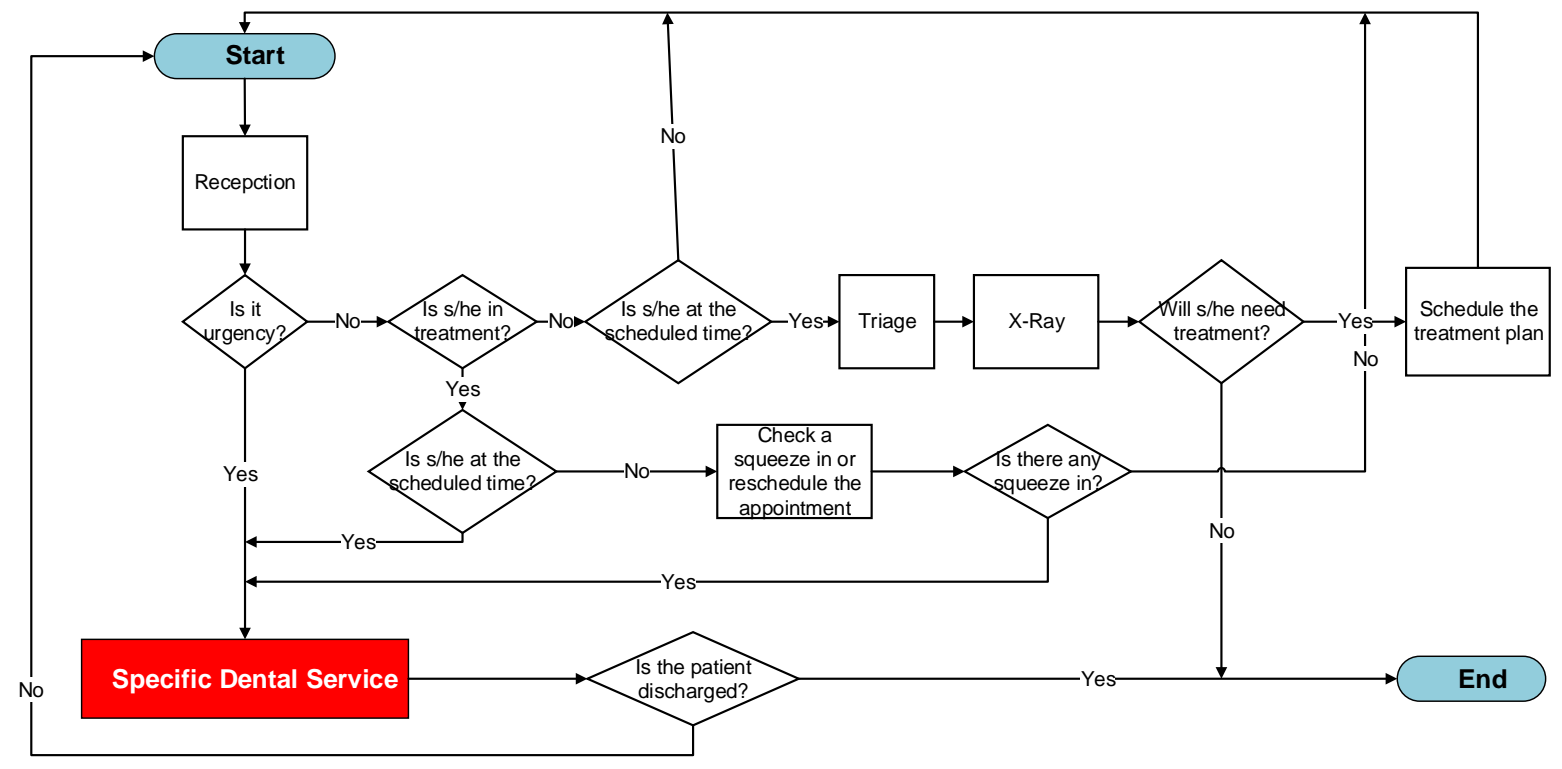




\section{PROCESSES OF THE DENTAL PROSTHESIS TREATMENT}

Figure 2 represents the process of dental prosthesis treatment. It notices that there are previous processes before the effective treatment execution. These previous processes refer to triage, where it is diagnosed which kind of treatment the patient needs. Next, s/he is referred to the reception to schedule the appointment(s). Depending on the case, the patient is also charged for the service. At this moment it is checked the patient link with the clinic, i.e. whether the patient is up to date with the monthly fee. If so, the patient is referred to the treatment, which may start on the same day or at a future date, depending on the respective availabilities. If the patient is late with the monthly fee, s/he has the option of settling it at that time if $s /$ he wants to do. Otherwise, s/he cannot go on with the treatment. These previous processes are regulars in the clinic and therefore they repeat before all the other processes (see Supplementary Materials: Fig. S1-S20).

Figure 2. Dental prosthesis process

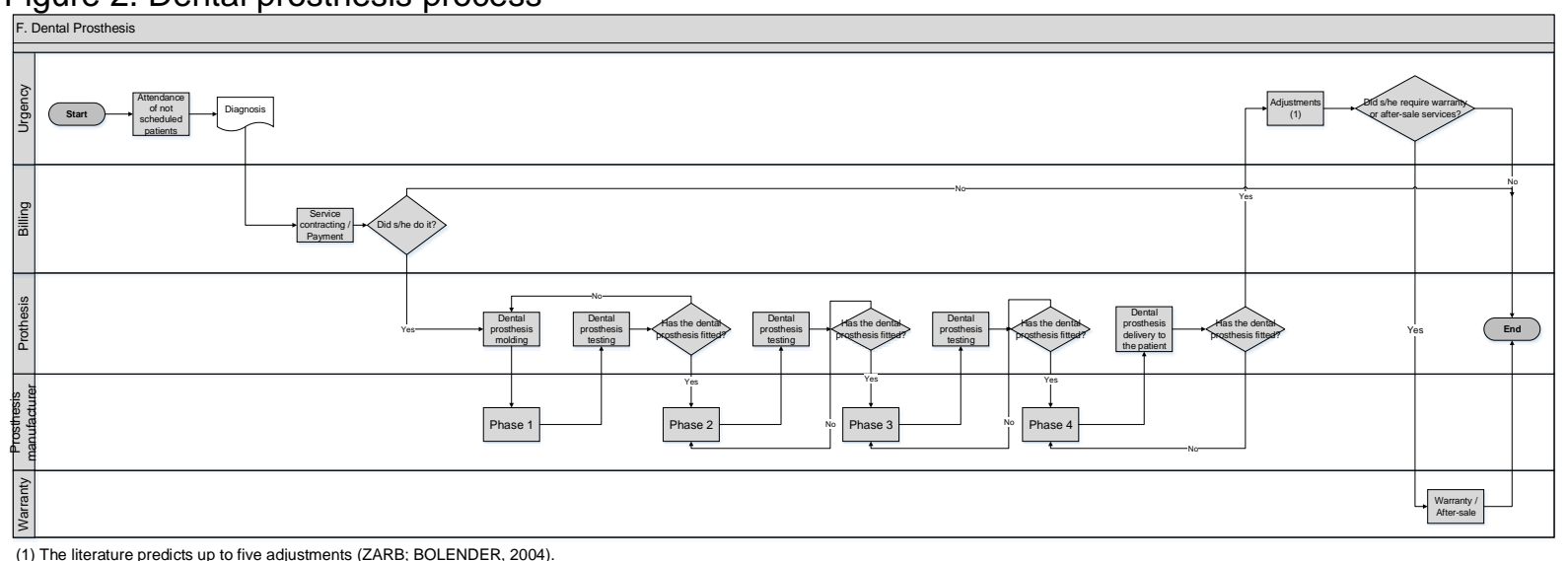

It draws attention here to the importance of these previous processes. They have an impact directly on the results of the clinic. As it can be noticed, this initial verification supports the organization both in the scheduling and in the workflow of the clinic, and also avoids the attendance of patients who have not paid their monthly fees. As with the orthodontics treatment, the dental prosthesis treatment is also charged. Likewise, it has the same rights and duties related to warranty as provided for the Código de Defesa do Consumidor.

Considering the patient interest to pass through dental prosthesis treatment, s/he contracts the services and schedules the appointments at billing and reception, respectively. The patient then starts the treatment on the same day or at a future date, depending on the respective availabilities.

Once the dental prosthesis treatment starts, in the first appointment the dental prosthesis molding is carried out and such mold is sent to the technician, who fabricates the dental prosthesis and, in turn, takes about a week to do it and sent it back to the clinic.

From the second appointment onward, prosthesis tests are done to check whether the dental prosthesis is suited to the patient's needs and characteristics. If so, it goes to the next stage of dental prosthesis manufacturing; if not so, it returns to the previous phase of 
adjustments and corrections. This cycle may repeat up to five times. It notices here a logistics relationship between dentist and technician, which requires well programming and well communication between them.

In the last appointment the patient receives the dental prosthesis (which may be partial or total, fixed or mobile) and after that s/he may make adjustments right on the urgency without previous scheduling. According to the literature, after the dental prosthesis delivery, it is predicted up to five adjustments (ZARB; BOLENDER, 2004).

From prosthesis delivery onward, the three-month warranty starts being counting, as provided for the Código de Defesa do Consumidor. If the patient needs to require for warranty, s/he is then referred to the competent sector and the case is analyzed. The patient usually goes to the clinic to make adjustments in the dental prosthesis during the warranty period. The dental prosthesis process ends after the adjustments and the requirement or not for warranty.

It was verified that the dental prosthesis treatment is the one that takes the longest time to be finished and has more processes. It was also noticed that the process is the one that most cause problems in the clinic. Furthermore, the technical coordinator also informed that there is a dentist observation (note) in the patient record regarding some error in the treatment, indicating that everybody knows that there may be the return of the patient and the requirement for warranty. This fact drew both researchers and interviewee attentions because it configures a critical point in the dental prosthesis treatment, which, in turn, features it from the other processes, and therefore requires attention. It was also informed by him (interviewee) that the dental prosthesis treatment is the most responsible for warranty activation, occurring many times more than the orthodontics does.

Once the patient is discharged, s/he may be added to the list of patients wholly met. However, when s/he comes back to the clinic as a result of problems from the treatment ever finished, s/he will be occupying a vacancy and time of attendance which a new patient could have been doing.

As such, and as a way to increase the number of patients seen at the clinic, i.e. seek to achieve the objectives of its business model, the board of directors could eliminate this more complicated and lengthy process, because it requires up to five appointments to be finished, and more than that, it has risks of steps repetition if the dental prosthesis does not successfully fit. This suggestion is based on studies such as Sánchez and Rodríguez (2007), Conrad et al. (2010), Ahmed and Amagoh (2014), and Longaray et al. (2015), who show ways of productivity measurement and controlling, as well as change or even elimination of process - either in whole or in part - as a way to increase productivity and eliminate bottlenecks.

Therefore, it was suggested and agreed that the dental prosthesis treatment would be performed by a partner clinic (outsourced). This decision can even strengthen commercial relations. 


\section{WARRANTY PROCESS}

The warranty process is activated either by the dental prosthesis treatment, as it is in the most of the time, or by the orthodontics treatment, which is the less frequent.

It also starts at the urgency sector, where the patient explains its needs and the dentist on duty makes a diagnosis. Many times the problem of the patient is successfully solved at that moment and so there is no warranty activation. If it is not possible to solve the problem at that moment, some criteria are analyzed to decide where the patient should be referred. In short, there are three criteria:

- The piece was damaged, and the dentist analysis concludes that it is not patient fault. In this case, the patient is then referred to the reception and billing, where the warranty is activated and the appointment is scheduled;

- The piece was damaged, and the dentist concludes it is a patient fault. $S / h e$ then does not have rights to require for warranty and is oriented to redo the treatment, which in turn will have its costs charged from the patient; or

- In some cases, there is a dentist observation in the patient report that was made by the one who has treated him (exclusively dental prosthesis treatment criterion). This observation, which was already mentioned, indicates that there would be the possibility of a patient return for warranty due to some error not uncommon that had occurred in the treatment. In this case, the patient is referred to the reception to schedule his/her retreatment, but there is no charging due to the mentioned observations.

Figure 3 shows the warranty process.

Figure 3. Flowchart of the warranty process

\begin{tabular}{|l|l|l|l|}
\hline 1. Warranty & \\
\hline
\end{tabular}




\section{COMMENTS ABOUT THE PROCESS MAPPING}

According to authors such as Sánchez and Rodríguez (2007), Toussaint (2013), Toussaint and Berry (2013), Oliveira S. (2014), and Rocha et al. (2014), the process standardization and the value stream mapping highlight the key activities of the process. These highlighting could be noted in this study since, when analyzing the flowcharts, the process of reception and billing is important (key activity) in two points of view:

- Economic: since it avoids to meet patients incorrectly linked (those who had not paid their monthly fees); and

- Arrangement: since both the verification and fulfillment of the appointment date and time allows that the workflow happens as scheduled and avoids disorganizing likewise.

This fact could also be noted in the study of Ahmed and Amagoh (2014), where the authors emphasize the importance of the role of the reception and billing to help the workflow.

The dental prosthesis treatment is a critical process in the clinic in question. As noticed, it stands out from the others because of its duration, complexity, dynamic, and mainly because of the problems it causes. Its characteristics go against the clinic's business model, which concerns in reaching a high quantity of patients seen in order to meet the largest parcel of the union members.

Another critical process is the warranty process. Although it happens in only two cases, i.e. dental prosthesis or orthodontics, it notices that the warranty process is onerous for the clinic since when it is activated, the treatment will be repeated without charge, and this affects the clinic economically.

According to the head of the dental clinic, the flowcharts represent the reality in the clinic and have cleared up to the clinic's employees and managers many stages that they did not even realize the existence. The Likert scale indicated maximum punctuation ( $5=$ strongly agree) for all the questions done.

According to the expert in management, the flowcharts correctly utilize the concepts of process mapping and process management (five-point Likert scale: $5=$ strongly agree).

\section{A GENERIC FRAMEWORK FOR PROCESS MANAGEMENT IN DENTAL CLINICS}

Based on the performed process mapping and considering the concepts of process management, Figure 4 was elaborated as a proposal of a generic framework for process management in dental clinics.

The proposal is also based on what the literature predicts with regards to the need 
of process standardization and management to ensure the survival of the organizations in the competitive market, as well as to enhance the possibility of meeting their business models (LAGIOIA et al., 2008; PINOCHET; LOPES; SILVA, 2014; ROCHA et al., 2014; ROHNER, 2012).

Figure 4. A generic framework for dental clinics based on process management

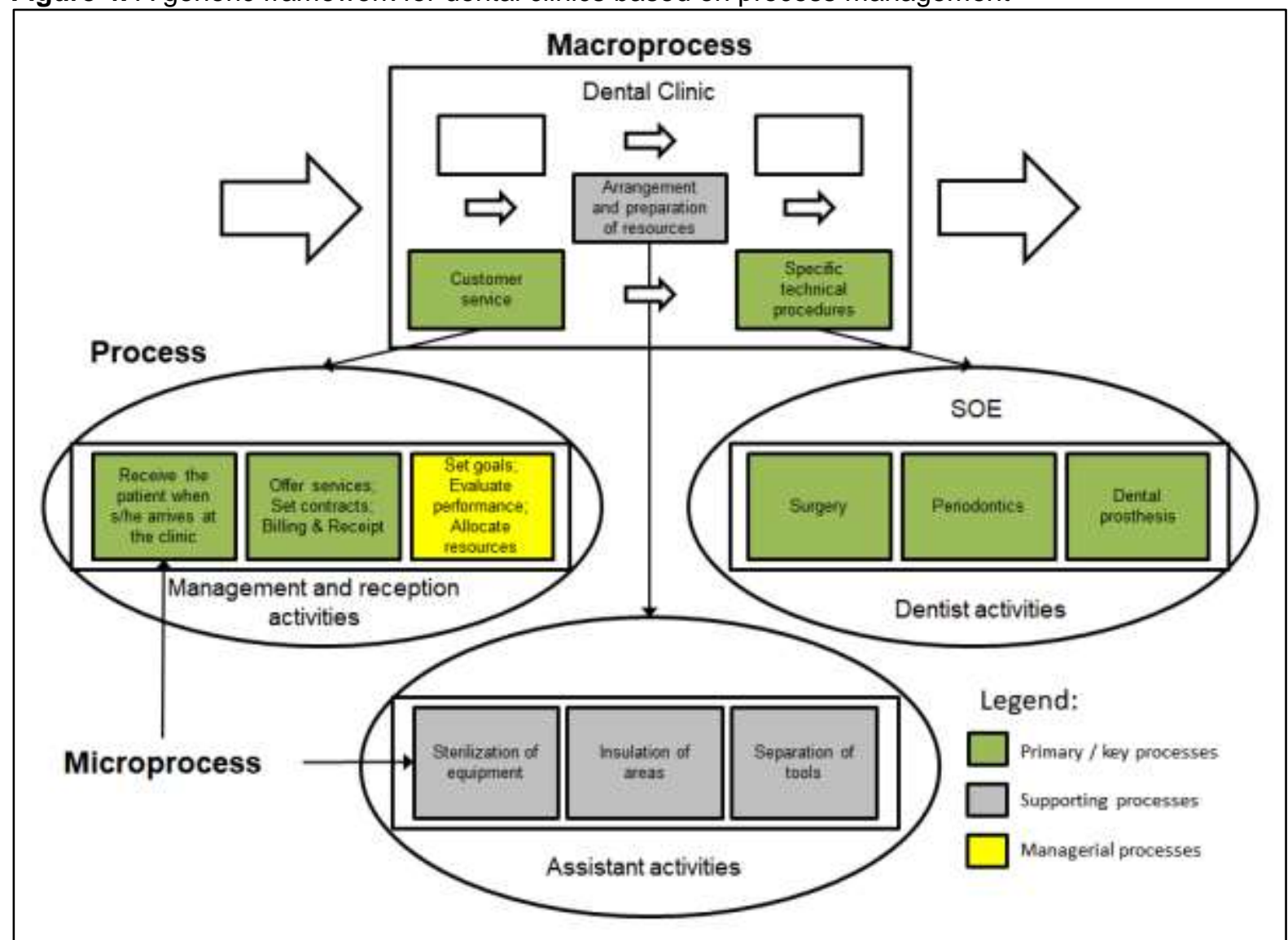

Source: Elaborated by the authors based upon Slack, Brandon-Jones and Johnston (2015), Gonçalves (2000), Rohner (2012), Rotondaro (2012), Sánchez and Rodríguez (2007), and Oliveira S. (2014).

\section{DISCUSSION}

The low demand for dental services offered by ambulatories, or union dental office/clinic, or enterprise dental office/clinic, or first aid post, or emergency, or hospital, which keeps a constant at least since 1998, according to PNADs data (BARROS; BERTOLDI, 2002; IBGE, 2000, 2010), remains neglected despite favorable prospects to the expansion on the provision of private or associated dental services which were pointed out by previous studies (JUNQUEIRA; RAMOS; RODE, 2005; PIETROBON et al., 2008; SERRA; HENRIQUES, 2000; SILVEIRA; OLIVEIRA, 2002). In this context, the results of this present study have two practical implications: first, they show the variety of services that a union dental clinic can provide, and, indirectly, reinforce the need of popularizing these dental service providers that remain neglected and rarely used; second, they present utilities of a managerial tool that may help to achieve business models of dental clinics. 
This research has demonstrated that the process mapping provides for companies an understanding regarding their routines and sequences of their activities, and it serves as a basis for making decisions. The process modeling of the clinic's processes has provided a macro vision and made possible to understand the usefulness of each process and identify both the hierarchy of the processes and the key processes, allowing for understanding the process flow and thus opening opportunities for improvements, corroborating what Araujo (2001), Cury (2000), Oliveira D. (2007), Oliveira S. (2014), and Slack, Brandon-Jones and Johnston (2015) affirm.

Before this research, there was no documenting organizing in the dental clinic, and the routines in all the sectors were carried out without a programmed sequence. The elaborated flowcharts made possible for both the employees and managers of the clinic to know many stages that they did not even realize the existence. Oliveira S. (2014) emphasizes the documental control, i.e. the elaboration of control manuals and guidelines to rule all the processes of an organization. This mapping is a document that helps the clinic's organizing. More than that, Rohner (2012) remembers that before to run management projects in practice it is useful first to understand how they work and run them "on paper". Slack, Brandon-Jones and Johnston (2015) also conceptualize about it.

Authors such as Lagioia et al. (2008), Llanes-Font et al. (2014), and Rocha et al. (2014) say that the purpose of process management is to improve the efficiency and effectiveness of organizations to reach defined objectives and so to keep a pace of continuous improvement of the service quality. The decision of eliminating the dental process treatment from the list of processes of the clinic takes into account the characteristics of such treatment since it differs from the others regarding time and dynamism. As such, how much more similar the processes behaviors of the clinic were, much more comfortable they will be standardized and then the heads of the clinic can actively dedicate to continuous improvement of the quality of the services which they put themselves disposed to offer.

As Rocha et al.'s (2014) study, the process mapping and the organizing carried out in the clinic allowed for identifying the hierarchy of the processes, the key processes, and the critical points. With the implantation of process management, the dental clinic's processes may be standardized and sequenced to improve the quality of the services provided by it.

The solution suggested in this present study regarding the problems in the dental prosthesis process cannot be generalized. In the case studied herein, such decision aimed at supporting the business model of the clinic object of study. However, remembering the situation, at the end of the dental prosthesis treatment there was an observation from the dentist regarding some error in the treatment, which indicated that everybody was aware that there could be the return of the patient and the requirement for warranty. Beyond simple criticism, another way to solve the situation would be the clinic's team to meet and define steps in the treatment prioritizing the rigor in the process to maximally avoid errors (OLIVEIRA S., 2014; ROCHA et al., 2014; SLACK; BRANDON-JONES; JOHNSTON, 2015) 
that could result in the requirement for warranty. For such, quality tools could be considered.

The suggested elimination considers what authors such as Oliveira, S. (2014), Rotondaro (2012), Rohner (2012) and UNICAMP (2003) say about the first need of defining the strategic objectives of the company to then run towards them. Being the clinic's strategic objective, according to the technical coordinator, to meet, with quality, as many patients as possible, the decision of eliminating the dental prosthesis treatment was a way to reach such objective. It does not mean to always opt for eliminating a treatment in case of searching for improvements. It is necessary to remember that this suggestion is a decision in line with the strategic objectives.

If a similar problem were noticed in a private clinic, for example, the dental prosthesis treatment would need to pass through analysis which could consider economic and financial variables, such as Pareto analysis (ABC Curve) (e.g. CARVALHO; PALADINI, 2012; SLACK; BRANDON-JONES; JOHNSTON, 2015) or accounting and budget evaluation (e.g. GITMAN, 2010; MÜLLER; TELÓ, 2003). Such analysis should be made based upon historical reports and registers which could indicate whether such treatment is profitable or onerous to the clinic since private clinics focus on profitability (PRASAD; VARATHARAJAN, 2011; SORIA; BORDIN; COSTA FILHO, 2002).

Despite that, points addressed by Rohner (2012) and Lagioia et al. (2008) should be mentioned here. When regards to the practicalities that these kinds of management seek to provide, peculiar characteristics existing in the health field need to be considered. Such characteristics refer to patients since, either in a hospital or a dental clinic, each patient is a unique case, and each has its particular recovery time and response to treatment. Additionally, there is also the fact that a particular treatment may result in a referral to another, such as the in clinic studied, where the endodontic treatment (D.2. paraendodontic) may refer to the surgery (A.1. exodontics), or the clinic (B.1. restoration), or the implantation (F. dental prosthesis). This variation corroborates the fact that each patient is unique and its diagnosis defines what should be done for him/her, and therefore s/he cannot and should not be "plastered" within a system.

On the other hand, when suggesting in this study the organizing and later the processes standardization, it does not intend to treat the clinic's patients as merely entities ${ }^{1}$ within a system, but rather to offer a sequencing to the process steps. Such sequencing aims to give uniformity to the clinic's routine, as well as an organized technical sequence based on evidence and in which, once registered, constant improvements may be carried out, like quality management values. So, process standardization concerns in defining the sequences of all the processes and their interfaces and interconnections, which may or may not be used, depending on each patient's need and peculiarity (LAGIOIA et al., 2008; ROHNER, 2012). So, the patients will continue receiving the due treatment and having their needs met according to diagnosis, but the clinic as a whole will also have its workflow controlled and will know what happens in it and where to act to improve it. The benefits of this kind of management are supported by Lagioia et al. (2008), Rohner (2012) and Rocha et al. (2014), among others. 
Initiatives of macro domains such as public policy and awareness actions concerned with improving the well-being of the population and increasing access to health (ANTUNES, NARVAI, 2010, BARROS, BERTOLDI, 2002, CHAVES et al., 2017, MATOS et al., 2002) are ways to reach a more considerable portion of potential users of dental services, but these attitudes may also derive from dental clinics. Strategic management focused on business is a way to increase the number of patients seen, as other existing ways, such as larger divulgation of which services are provided, which may be achieved through advertising and marketing tools (KOTLER; KELLER, 2012) or innovative initiatives (SILVA et al., 2015), which are currently on the top, especially in the technological field (CARVAJAL JR.; CRIVELARO; SANCHEZ, 2017; LI; HOU; WU, 2017; MAYNARD, 2015; SANCHEZ; FREITAS, 2015).

This study has practical contributions to Science since it provides a generic framework for health managers that may help them to orient their clinics based upon processes to seek the increase of service quality, productivity, or patient satisfaction; and impulses studies on less popular dental clinics, such as the unions'.

\section{CONCLUSION}

The results indicate that it is possible to manage a dental clinic starting from process mapping, and this helps in their strategic organization and forms a base for decision-making, which may be a competitive advantage for the clinic. With regards to union dental clinics, process mapping may help them to make decisions to minimize problems or increase the number of patients seen in.

It is important to observe the limitations of this study, which is the lack of measurement of the results, the number of patients seen in the clinic with or without the dental prosthesis process, and the customer perception of service quality, which should be made based upon indicators. It is acknowledged that this kind of measurement should be made through experimental research, which first demands prior studies to be used as a support, such as this one.

Process mapping is an initial step of documenting and standardizing the processes of the clinic in order to make it more strategically organized. It is suggested for future research to elaborate a guide on how to apply process management in dental clinics according to their business models.

Studies to measure the productive, utilization, and efficiency indexes of the sectors of the clinic could also be conducted, similar to the studies of Ahmed and Amagoh (2014) and Conrad et al. (2010). In doing that it would be possible to verify results of managerial techniques from another perspective, and perhaps to combine process management approach with production management. Simulation tools could be helpful in this context.

Due to the characteristics of the dental clinic studied herein, some of the findings of this study are valid only for clinics that seek to increase the productivity measured per 
patients seen. For clinics that the business model aims to earn a profit, further and addressed studies are necessaries. However, the mapping, identification, and prioritization of processes may be carried out everywhere.

This research does not intend to exhaust the subject. Instead, it intends to add to the progress of studies on business management in the oral health care services, and thus, in the future, reach levels of studies in such field as there are currently in hospital management.

\section{ACKNOWLEDGMENTS}

The authors thank the National Council for Scientific and Technological Development (CNPq) for research productivity grant (CA-PE level 2) awarded to L.T.K.J.; the National Council for the Improvement of Higher Education (CAPES) for Scholarship for master degree course awarded to L.A.S.S.N.; the University of Mogi das Cruzes (UMC) and Federal Institute of São Paulo (IFSP) for their support.

\section{NOTES}

1. Word used in simulation studies to refer to the variable that is being analyzed in a system, which could be people, products, information etc.

\section{REFERÊNCIAS}

AGÊNCIA NACIONAL DE SAÚDE SUMPLEMENTAR. Resolução Normativa (RN) no 137, de 14 de novembro de 2006 (e alterações). Dispõe sobre as entidades de autogestão no âmbito do sistema de saúde suplementar. Available at:

<http://www.ans.gov.br/component/legislacao/>. Accessed: 03 mar. 2018.

AHMED, S.; AMAGOH, F. Process analysis and capacity utilization in a dental clinic in Kazakhstan. Competitiveness Review, v. 24, n. 4, p. 347-356, 2014.

AL-DWAIRI, Z. N. Infection control procedures in commercial dental laboratories in Jordan. Journal of Dental Education, v. 71, n. 9, p. 1223-1227, 2007.

; AL-OMARI, M. A. Compliance with infection control programs in private dental clinics in Jordan. Journal of Dental Education, v. 69, n. 6, p. 693-698, 2005.

ALI, M.; SON, L. H.; KHAN, M.; TUNG, N. T. Segmentation of dental X-ray images in medical imaging using neutrosophic orthogonal matrices. Expert Systems with Applications, v. 91, p. 434-441, January 2018.

ALMEIDA NETO, M. A. Ferramentas de Modelagem e Gestão do Processo de Negócio. In: OLIVEIRA, S. B. (organizador). Gestão por processos: fundamentos, técnicas e 
modelos de implementação. 2. ed. 3. reimpr. Rio de Janeiro: Qualitymark Editora, 2014. cap. 7, p. 231-295.

ANDER-EGG, E. Introducción a las técnicas de investigación social: para trabajadores sociales. 7. ed. Buenos Aires: Humanitas, 1978.

ANTUNES, J. L. F.; NARVAI, P. C. Políticas de saúde bucal no Brasil e seu impacto sobre as desigualdades em saúde. Revista de Saúde Pública, v. 44, n. 2, p. 360-365, 2010.

ARAUJO, L. C. G. Análise de processos - fluxogramas. In: Organização, sistemas e métodos e as modernas ferramentas de gestão organizacional: arquitetura, benchmarking, empowerment, gestão pela qualidade total, reengenharia. São Paulo: Atlas, 2001. cap. 5, p. 64-81.

BAHADORI, M.; RAADABADI, M.; RAVANGARD, R.; BALDACCHINO, D. Factors affecting dental service quality. International Journal of Health Care Quality Assurance, v. 28, n. 7, p. 678-689, 2015.

BALDWIN, A.; SOHAL, A. Service quality factors and outcomes in dental care. Managing Service Quality, v. 13, n. 3, p. 207-216, 2003.

BARROS, A. J. D.; BERTOLDI, A. D. Desigualdades na utilização e no acesso a serviços odontológicos: uma avaliação em nível nacional. Ciência \& Saúde Coletiva, v. 7, n. 4, p. 709-717, 2002.

BRASIL. Ministério da Previdência e Assistência Social. Ministério da Saúde. Lei no. 9656 (Lei Ordinária), de 03 de junho de 1998. Dispõe sobre os Planos e Seguros Privados de Assistência à Saúde. Diário Oficial da União. Poder Legislativo, Brasília, DF, 03 jun. 1998, p. 1.

Ministério da Saúde. Diretrizes da política nacional de saúde bucal. Brasília: Ministério da Saúde, 2004.

CAMGÖZ-AKDAĞ, H.; ZINELDIN, M. Quality of health care and patient satisfaction: an exploratory investigation of the 5Qs model at Turkey. Clinical Governance: An International Journal, v. 15, n. 2, p. 92-101, 2010.

;; ÇALIŞKAN, E.; TOMA, S. Lean process design for a radiology department. Business Process Management Journal, v. 23, n. 4, p. 779-791, 2017.

CARVAJAL JR., C. J.; CRIVELARO, M.; SANCHEZ, W. M. (organizadores). Tendências e oportunidades de negócios para empreendedores digitais. São Paulo: Porto de Ideias, 2017.

CARVALHO, M. M.; PALADINI, E. P. Gestão da qualidade: teoria e casos. 2. ed. Rio de Janeiro: Elsevier: ABREPO, 2012.

CASSOL, T.; DULLIUS, A. I. S.; ANSUJ, A. P. Perspectivas do acadêmico de odontologia de universidades do interior do Rio Grande do Sul-Brasil. Revista ESPACIOS, v. 37, n. 33, 2016.

CHAVES, S. C.; ALMEIDA, A. M.; ROSSI, T. R.; SANTANA, S. F.; BARROS, S. G.; SANTOS, C. M. Política de Saúde Bucal no Brasil 2003-2014: cenário, propostas, ações e 
resultados. Ciência \& Saúde Coletiva, v. 22, n. 6, p. 1791-1803, 2017.

CHOI, K. S.; LEE, H.; KIM, C.; LEE, S. The service quality dimensions and patient satisfaction relationships in South Korea: comparisons across gender, age and types of service. Journal of Service Marketing, v. 19, n. 3, p. 140-149, 2005.

CONRAD, D. A.; LEE, R. S. Y.; MILGROM, P.; HUEBNER, C. E. Estimating determinants of dentist productivity: new evidence. Journal of Public Health Dentistry, v. 70, n. 4, p. 262-268, 2010.

CONSELHO FEDERAL DE ODONTOLOGIA - CFO. Consolidação das Normas para Procedimentos nos Conselhos de Odontologia, aprovada pela Resolução CFO-63/2005, atualizada em 18 de maio de 2005. Diário Oficial da União, v. 19, p. 104, 2005. Available at: <http://www.crors.org.br/legislacao/>. Accessed: 02 feb. 2018.

CONSELHO REGIONAL DE ODONTOLOGIA DE SÃO PAULO - CROSP. Homepage. (2017a). Available at: <http://www.crosp.org.br>. Accessed: 26 jun. 2017.

Manual de Orientação para Pessoas Jurídicas e Empresários (Individuais). (2017b). Available at: <http://www.crosp.org.br>. Accessed: 13 jun. 2017.

COULTHARD, B. D. S. P.; HELEN, V. W. The efficacy of various bone augmentation procedures for dental implants: a Cochrane systematic review of randomized controlled clinical trials. The International Journal of Oral \& Maxillofacial Implants, Sep-Oct; v. 21, n. 5, p. 696-710, 2005.

COVRE, E.; ALVES, S. L. Planos odontológicos: uma abordagem econômica no contexto regulatório. Rio de Janeiro: ANS, 2002.

CURY, A. Gráficos de processamento. In: Organização e métodos: uma visão holística. 7. ed. rev. e ampl. São Paulo: Atlas, 2000. cap. 11, 329-360.

DALL'ORSOLETTA, D.; XAVIER, P. B. Intersetorialidade: conhecimento dos gestores e a sua aplicabilidade nas políticas públicas de saúde. Revista Interdisciplinar de Estudos em Saúde, Caçador, v. 5, n. 1, p. 12-20, 2016.

DESCRITORES EM CIÊNCIAS DA SAÚDE - DeCS. Homepage. Available at: <http://decs.bvs.br>. Accessed: 03 feb. 2018.

DOMÉJEAN, S.; BANERJEE, A.; FEATHERSTONE, J. D. B. Caries risk/susceptibility assessment: its value in minimum intervention oral healthcare. British Dental Journal, v. 223, n. 3, p.191-197, 2017.

FERRARI, A. T. Metodologia da pesquisa científica. São Paulo: McGraw-Hill do Brasil, 1982. Capítulo 10.

GARZA-REYES, J. A. A systematic approach to diagnose the current status of quality management systems and business processes. Business Process Management Journal, v. 24, n. 1, p. 216-233, 2018.

GIL, A. C. Como elaborar projetos de pesquisa. 5. ed. São Paulo: Atlas, 2010.

GITMAN, L. J. Princípios de Administração Financeira. 12. ed. São Paulo: Pearson 
Prentice Hall, 2010.

GOLDRATT, E. M.; COX, J. A meta: um processo de melhoria contínua. 2. ed. São Paulo: Nobel, 2014.

GONÇALVES, J. E. L. As empresas são grandes coleções de processos. RAE-Revista de Administração de Empresas, v. 40, n.1, p. 6-19, 2000.

GOZZI, M. P. (organizador). Gestão da Qualidade em bens e serviços. São Paulo: Person Education do Brasil, 2015. - (Coleção Bibliografia Universitária Pearson)

HAMMER, M.; CHAMPY, J. Reengenharia: revolucionando a empresa em função dos clientes, da concorrência e das grandes mudanças da gerência; tradução de Ivo Korytowski. Rio de Janeiro: Campus, 1994.

HOLMES, P. B.; SHROFF, B.; BEST, A. M.; LINDAUER, S. J. Influence of gender on office staff management in orthodontics. The Angle Orthodontist, v. 80, n. 6, p. 11501154, 2010.

INSTITUTO BRASILEIRO DE GEOGRAFIA E ESTATÍSTICA - IBGE. Acesso e utilização de serviços de saúde. PNAD 1998. Rio de Janeiro: IBGE, 2000.

2010.

Acesso e utilização de serviços de saúde. PNAD 2008. Rio de Janeiro: IBGE,

JUNQUEIRA, C. R.; RAMOS, D. L. P.; RODE, S. M. Considerações sobre o mercado de trabalho em odontologia. Revista Paulista de Odontologia, v. 27, n. 4, p. 24-27, 2005.

KAWAMOTO JR., L. T.; KAWAMOTO, W. O.; FORMIGONI, A.; RODRIGUES, E. F.; CAMPOS, I. P. A.; RODRIGUES, S. C. M. Quality Comparison of Analog and Digital XRay Equipment and Materials in a Dental Clinic. Key Engineering Materials, v. 660, p. 330-334, 2015. Trans Tech Publications.

KIRCHMER, M.; LAENGLE, S.; MASIAS, V. Transparency-Driven Business Process Management in Healthcare Settings [Leading Edge]. IEEE Technology and Society Magazine, v. 32, n. 4, p. 14-16, 2013.

KOHN, W. G.; COLLINS, A. S.; CLEVELAND, J. L.; HARTE, J. A.; EKLUND, K. J.; MALVITZ, D. M. Guidelines for infection control in dental health-care settings-2003. MMWR Recomm Rep, v. 52, n. 17, p. 1-61, 2003.

KOTLER, P.; KELLER, K. L. Administração de Marketing. 14. ed. São Paulo: Pearson Education do Brasil, 2012.

LAGIOIA, U. C. T.; RIBEIRO FILHO, J. F.; FALK, J. A.; LIBONATI, J. J.; LOPES, J. E. G. A gestão por processos gera melhoria de qualidade e redução de custos: o caso da unidade de ortopedia e traumatologia do hospital das clínicas da Universidade Federal de Pernambuco. Revista Contabilidade \& Finanças, v. 19, n. 48, p. 77-90, 2008.

LI, G.; HOU, Y.; WU, A. Fourth Industrial Revolution: technological drivers, impacts and coping methods. Chinese Geographical Science, v. 27, n. 4, p. 626-637, August 2017.

LIN, F. R.; YANG, M. C.; PAI, Y. H. A generic structure for business process 
modeling. Business Process Management Journal, v. 8, n. 1, p. 19-41, 2002.

LLANES-FONT, M.; ISAAC-GODÍNEZ C. L.; MORENO-PINO, M.; GARCÍA-VIDAL, G. De la gestión por procesos a la gestión integrada por procesos. Ingeniería Industrial, v. 25, n. 3, p. 255-264, set-dez, 2014.

LONGARAY, A. A.; MUNHOZ, P. R.; SIMÃO ALBINO, A.; CASTELLI, T. M. Use of BPM to redesign the container handling process: a Brazilian retroportuary terminal case. Independent Journal of Management \& Production (IJM\&P), v. 6, n. 3, p. 667686, 2015.

MARCONI, M. A.; LAKATOS, E. M. Metodologia científica. 5. ed. 2. reimpr. São Paulo: Atlas, 2008.

2009.

Fundamentos de metodologia científica. 6. ed. São Paulo: Atlas,

MARTINS, R. G.; MAYSÉS, R. P. C.; VALLE, F. F.; VALLE, V. A. F.; SOUZA, C. S. M.; BARCELLOS, J. F. M. "Programa saúde e cidadania": a contribuição da extensão universitária na Amazônia para a formação médica. Revista de Medicina, São Paulo, v. 95, n. 1, p. 6-11, 2016.

MATOS, D. L.; LIMA-COSTA, M.; GUERRA, H. L.; MARCENES, W. Projeto Bambuí: avaliação de serviços odontológicos privados, públicos e de sindicato. Revista de Saúde Pública, v. 36, n. 2, p. 237-243, 2002.

MAYNARD, A. D. Navigating the fourth industrial revolution. Nature Nanotechnology, v. 10, 2015. p. 1005-1006.

MCCANN, K.; LINK, R. C. Dental health: the probability of dental insurance coverage and utilization of dental care. In: iHEA - 6th World Congress: Explorations in Health Economics, Copenhagen, 8-11 July, 2007. Anais... Copenhagen, 2007. Available at: <http://ssrn.com/abstract1/1/4993797>. Accessed: 02 feb. 2018.

MEYER, C.; SCHWAGER, A. Understanding customer experience. Harvard Business Review, v. 85, n 2, p. 116-126, 2007.

MINAYO, M. C. S. (organizadora). Pesquisa social: teoria, método e criatividade. Petrópolis, RJ: Vozes, 2016. (Série Manuais Acadêmicos)

MORRIS, M.; SCHINDEHUTTE, M.; ALLEN, J. The entrepreneur's business model: toward a unified perspective. Journal of Business Research, v. 58, n. 1, p. 726-735, 2005.

MÜLLER, A. N.; TELÓ, A. R. Modelos de avaliação de empresas. Revista da FAE, v. 6, n. 2, p. 97-112, 2003.

NELSON, I. M. Basic bookkeeping and avoiding theft. Dental Clinics of North America, v. 52, n. 3, p. 529-534, 2008.

OLIVEIRA, D. P. R. Técnicas de Representação Gráfica. In: Sistemas, Organização \& Métodos: Uma Abordagem Gerencial. 17. ed. São Paulo: Atlas, 2007. cap. 10 , p. $257-300$. 
OLIVEIRA, S. B. (organizador). Gestão por processos: fundamentos, técnicas e modelos de implementação. 2. ed. 3. reimpr. Rio de Janeiro: Qualitymark Editora, 2014.

; MOTTA, R. A. S. M.; OLIVEIRA, A. S. Gestão de processos e tecnologia de informação: em busca da agilidade em serviço. Revista Gestão.Org., v. 10, n. 1, p. 172194, jan./abr. 2012.

OHNO, T. O sistema Toyota de Produção: além da produção em larga escala ; trad. Cristina Schumacher. Porto Alegre: Bookman, 1997.

OYADOMARI, J. C.; PEDRIQUE, A. L.; BIDO, D. S.; REZENDE, A. Management Control Use and Decisions in Brazilian Health Organizations: an Exploratory Study. BBR, Braz. Bus. Rev., Vitória, v. 11, n. 2, p. 1-32, mar.-abr. 2014.

PAULA, F. J. D.; MUÑOZ, D. R.; SILVA, M. D.; MOTTA, M. V. D. Reclamações fundamentadas sobre o tratamento dentário no Procon da cidade de São Paulo (20062010). Revista da Associação Paulista de Cirurgiões Dentistas, v. 67, n. 1, p. 56-63, 2013.

PELS, J.; KIDD, T. A. Business model innovation: Learning from a hightech-low-fee medical healthcare model for the BOP. International Journal of Pharmaceutical and Healthcare Marketing, v. 9, n. 3, p.200-218, 2015.

PIETROBON, L.; SILVA, C. M.; BATISTA, L. R.; CAETANO, J. C. Planos de assistência à saúde: interfaces entre o público e o privado no setor odontológico. Ciência \& Saúde Coletiva, v. 13, n. 5, p. 1589-1599, 2008.

PINOCHET, L. H. C.; LOPES, A. S.; SILVA, J. S. Inovações e tendências aplicadas nas tecnologias de informação e comunicação na gestão da saúde. Revista de Gestão em Sistemas de Saúde - RGSS, v. 3, n. 2, p. 11-29, jul./dez. 2014.

PINTO, M. L. Percepção do cirurgião dentista sobre acreditação em odontologia. 2015. 114 f. Dissertação (Mestrado) - Universidade Nove de Julho - UNINOVE, São Paulo, 2015.

PIRES, S. R. I. Gestão da cadeia de suprimentos: conceitos, estratégias, práticas e casos - Supply chain management. 2. ed. 9. reimpr. São Paulo: Atlas, 2014.

PRASAD, B.M.; VARATHARAJAN, D. Using dental care resources optimally: Quality efficiency trade-offs in a competitive private market. International Journal of Health Care Quality Assurance, v. 24, n. 4, p. 284-299, 2011.

ROCHA, T. A. H.; RODRIGUES, J. M.; SILVA, N. C.; BARBOSA, A. C. Q. Gestão de recursos humanos em saúde e mapeamento de processos - reorientação de práticas para promoção de resultados clínicos satisfatórios. Revista de Administração Hospitalar e Inovação em Saúde, v. 11, n. 3, p. 143-159, 2014.

ROHNER, P. Achieving impact with clinical process management in hospitals: an inspiring case. Business Process Management Journal, v. 18, n. 4, p. 600-624, 2012.

ROTONDARO, R. G. Gerenciamento por Processos. In: CARVALHO, M. M.; PALADINI, E. P. Gestão da qualidade: teoria e casos. 2. ed. Rio de Janeiro: Elsevier: ABREPO, 
2012. cap. 7, p. 211-237.

SAM, F. E.; BONNICK, A. M. Office computer systems for the dental office. Dental Clinics of North America, v. 55, n. 3, p. 549-557, 2011.

SÁNCHEZ, J. J. Z.; RODRÍGUEZ, M. B. Indicadores de la calidad em los centros sociosanitarios del grupo Capio Sanidad. Gerokomos, v. 18, n. 1, p. 24-29, 2007.

SANCHEZ, W. M.; FREITAS, L. R. A Tecnologia da Informação e as oportunidades de negócios. In: CARVAJAL JR., C. J. et al. Empreendedorismo, tecnologia e inovação: como a TI está transformando a sociedade, a economia e gerando novas oportunidades para criação de Startups. São Paulo: Livrus Editorial, 2015. cap. 3, p. 47-69.

SÃO PAULO (Estado). Secretaria de Estado de Saúde. Coordenação dos Institutos de Pesquisa. Centro de Vigilância Sanitária. Aprova a Norma Técnica que estabelece condições para instalação e funcionamento de estabelecimentos de assistência odontológica, e dá providências correlatas. Resolução SS-15, de 18 de janeiro de 1999. Diário Oficial do Estado. Poder Executivo, Seção I, v. 109, n. 13, São Paulo, SP, 20 jan. 1999, p. 21. Available at: <https://www.imprensaoficial.com.br/DO/>. Accessed: 28 feb. 2018.

SERRA, M. C.; HENRIQUES, C. Participação de cirurgiões-dentistas em empresas de odontologia de grupo. Revista ABO Nacional, v. 8, n. 2, p. 80-85, 2000.

SILVA, A. S.; FARINA, M. C.; GOUVÊA, M. A.; DONAIRE, D. A Model of Antecedents for the Co-Creation of Value in Health Care: An Application of Structural Equation Modeling. BBR, Braz. Bus. Rev., Vitória, v. 12, n. 6, p. 124-153, nov.-dez. 2015.

SILVEIRA, J. L. G. C.; OLIVEIRA, V. Experiências e expectativas dos cirurgiões-dentistas com os planos odontológicos. Pesquisa Brasileira de Odontopediatria e Clínica Integrada, v. 2, n. 1, p. 30-34, 2002.

SLACK, N.; BRANDON-JONES, A.; JOHNSTON, R. Administração da Produção. 4. ed. São Paulo: Atlas, 2015.

SORIA, M. L.; BORDIN, R.; COSTA FILHO, L. C. Remuneração dos serviços de saúde bucal: formas e impactos na assistência. Cadernos de Saúde Pública, Rio de Janeiro, v. 18, n. 6, p. 1551-1559, Dez. 2002.

TAYLOR, F. W. Princípios de administração científica ; tradução de Arlindo Vieira Ramos. 8. ed. São Paulo: Atlas, 1990. Available at: <http://www.labest.eng.ufba.br>. Accessed: 20 mar. 2017.

THIOLLENT, M. Metodologia da pesquisa-ação. São Paulo: Cortez, 2013.

TOBÓN, L. F. A.; BOLÍVAR, J. E. Importancia de los procesos y su aplicación en las organizaciones. AD-minister, n. 4, p. 67-79, 2004.

TOUSSAINT, J. S. A management, leadership, and board road map to transforming care for patients. Frontiers of Health Services Management, v. 29, n. 3, p. 3-15, 2013.

; BERRY, L. L. The promise of Lean in health care. In: Mayo Clinic Proceedings, Elsevier, v. 88, n.1, p. 74-82, 2013. 
UNICAMP (2003). Gestão por processos. UNICAMP_170903.pdf. Available at: <http://www.prdu.unicamp.br/gestao_por_processos/>. Accessed: 23 feb. 2017.

VAN DER AALST, W. M. P. Business Process Management: A Comprehensive Survey. ISRN Software Engineering, vol. 2013, Article ID 507984, 37 pages, 2013.

ZARB, G. A.; BOLENDER C. L. Prosthodontic treatment for edentulous patients: Complete dentures and implant supported prostheses. 20. ed. St. Louis: Mosby, 2004.

ZILLI, M. G.; SANTOS, A. P. S.; YAMAGUCHI, C. K.; BORGES, L. A. Contribuições de uma clínica escola no atendimento em saúde no sul de Santa Catarina. Revista Interdisciplinar de Estudos em Saúde, Caçador, v. 6, n. 1, p. 105-116, 2017.

ZIROLDO, R. R.; GIMENES, R. O.; CASTELO JR., C. A importância da Saúde Suplementar na demanda da prestação dos serviços assistenciais no Brasil. O Mundo da Saúde, São Paulo, v. 37, n. 21, p. 216-221, 2013.

ZOTT, C.; AMIT, R.; MASSA, L. The business model: recent developments and future research. Journal of Management, v. 37, n. 4, p. 1019-1042, 2011. 